\title{
Canadian Companies Beware: THE U.S. FOREIGN CORRUPT PRACTICES ACT APPLIES TO YOU!
}

\author{
ROBERT A. BASSETT, ESQ.
}

This article outlines how the U.S. Foreign Corrupt Practices Act applies to non-U.S. corporations and individuals, with particular reference to those entities in Canada. The author points out the dual requirements of the legislation - the accounting provisions and the anti-bribery provisions - and explains how the generous wording of those provisions frequently makes them applicable to Canadian corporations and individuals, both directly and indirectly. Several cases are cited as examples of enforcement of the Act against nonU.S. corporations and individuals. The accounting provisions of the U.S. Securities and Exchange Commission are reviewed, as are the anti-bribery provisions of the U.S. Department of Justice.
Le présent article décrit en quoi la Foreign Corrupt Practices Act américaine s'applique aux sociétés et aux particuliers non américains - aux entités situées au Canada, notamment. Avec exemples à l'appui, l'auteur souligne les exigences doubles de la loi - les dispositions relatives aux pratiques comptables et les dispositions anticorruption - et montre comment. par leur formulation, ces dispositions s'appliquent fréquemment aux sociétés et aux ressortissants canadiens, directement et indirectement. $\dot{A}$ titre d'illustrations, il examine les dispositions de la US Securities and Exchange Commission en matière de comptabilité et les dispositions anti-corruption du ministère américain de la Justice.

\section{TABLE OF CONTENTS}

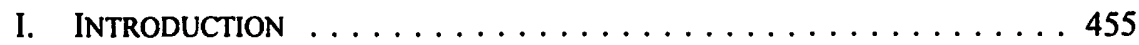

II. ENACTMENT OF THE FCPA $\ldots \ldots \ldots \ldots \ldots \ldots \ldots \ldots 46$

III. HISTORY OF ENFORCEMENT $\ldots \ldots \ldots \ldots \ldots \ldots \ldots \ldots \ldots 456$

IV. IMPORTANCE OF THE FCPA TO CANADIAN COMPANIES $\ldots \ldots .457$

V. APPLICATION OF THE FCPA TO NON-U.S. COMPANIES $\ldots \ldots \ldots 458$

A. DiReCt APPLICABILITY:
ISSUERS of SECURITIES $\ldots \ldots \ldots \ldots \ldots \ldots \ldots \ldots 458$

B. INDIRECT APPLICABILITY:

SUBSIDIARIES OF U.S. COMPANIES $\ldots \ldots \ldots \ldots \ldots \ldots \ldots 40$

VI. REQUIREMENTS OF THE $F C P A \ldots \ldots \ldots \ldots \ldots \ldots \ldots \ldots 461$

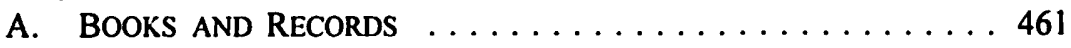

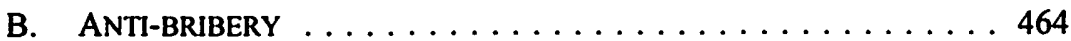

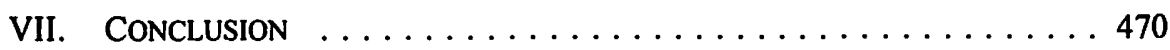

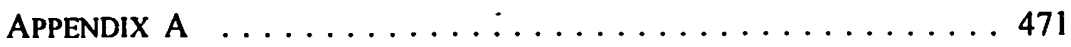

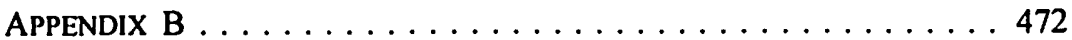

\section{INTRODUCTION}

The Foreign Corrupt Practices Act ${ }^{1}$ affects many Canadian resource companies directly. This United States law applies to every Canadian company which has subsidiaries in the U.S., which raises money in the U.S., which joint-ventures with a U.S. company or which is a subsidiary of a U.S. company. 
The FCPA has both accounting provisions and anti-bribery provisions. Enforcement is through civil and criminal penalties. Non-U.S. companies have paid multimilliondollar fines for failure to comply with the $F C P A$. One individual has been extradited from a foreign country and jailed in the U.S. under the $F C P A$ even though he was not a U.S. citizen.

This article will focus on the ways in which the FCPA has been applied to non-U.S. companies, particularly those in the resources industry. After a brief review of the $F C P A$ 's enactment and enforcement history, this article will examine when the $F C P A$ applies to non-U.S. companies and enforcement actions which have been taken against them.

\section{ENACTMENT OF THE FCPA}

During 1976 and 1977, the U.S. Congress became increasingly concerned with the conduct of international business, as a reaction to embarrassing public disclosures of payments made by prominent American companies to political officials in foreign countries, to secure high-value military contracts. U.S. investigators had learned that several prominent companies maintained secret accounts and slush funds that were used to make arrangements thought necessary to secure defence contracts in foreign markets. ${ }^{2}$ According to the U.S. Commerce Department, investigations by the Securities and Exchange Commission (SEC) revealed that over 400 U.S. companies, including 117 of the Fortune 500 companies, ${ }^{3}$ admitted making questionable or illegal payments in excess of $\$ 300$ million to foreign government officials, politicians and political parties.

The FCPA was thus enacted and signed into law by President Carter on 20 December $1977 .^{4}$ The title of the FCPA is something of a misnomer, because it deals with only half of its content - the prohibition against foreign bribery. The other half of the law is a very broad section on record-keeping and accounting practices. ${ }^{5}$ These provisions apply to all companies that have stock registered with the SEC, not just those with foreign operations. ${ }^{6}$

\section{HISTORY OF ENFORCEMENT}

The FCPA addresses the corrupt payments problem in two ways: (1) by mandating accounting standards for public companies (issuers); and (2) by prohibiting payments

F. Schuchat, "How to Succeed in International Business and Comply with U.S. Laws Prohibiting Corrupt Payments, Without Losing Out to Foreign Competition" (1997) International Resources Law, Paper No. 7A (Denver: Rocky Mtn. Min. L. Fdn., 1997) at 7A-3.

3 J. Bialos \& G. Husisian, "The Foreign Corrupt Practices Act: Dealing with Illicit Payments in Transitional and Emerging Economies" 1 Foreign Corrupt Practices Act Reporter 103.023 [hereinafter FCPA Rep.].

4 L. Chen, "Corporate Counsel's Primer on the Foreign Corrupt Practices Act" I FCPA Rep. 101.001 .

s W.A. Hancock, ed., "Executive Legal Summary" I FCPA Rep. 100.001.

- Chen, supra note 4 at 101.025 . 
to foreign officials from issuers and U.S. companies with knowledge of a corrupt purpose. $^{7}$

The U.S. Department of Justice (DOJ) and the SEC divide responsibility for enforcing the $F C P A$. In essence, the DOJ enforces the anti-bribery provisions, and the SEC enforces the books and records provisions, although violations of both provisions are alleged in many actual cases brought by each agency. The DOJ brings its actions in the U.S. federal court system. When a case is appealed beyond the trial court level, a published decision is readily available, but if a case does not go beyond the trial court stage, only various types of official "releases" are readily available. ${ }^{8} \mathrm{~A}$ similar situation exists with actions brought by the SEC in administrative courts. Thus, judicial decisions interpreting the $F C P A$ are frequently not available and, for information, one must rely to a large extent on the administrative releases.

Relatively few cases have progressed beyond the investigation stage to result in prosecutions against companies or individuals. The vast majority of those that have gone beyond investigation involved the accounting provisions of the $F C P A$, and almost none involve a foreign company or foreign activities of any kind. In addition, the cases involving the anti-bribery provisions of the $F C P A$ have focused on payments made to high-level government officials. During the investigation stage, however, companies have spent tens of millions of U.S. dollars in order to defend their business practices.?

\section{Importance OF THE FCPA to Canadian COMPanies}

At the time the FCPA was enacted, one commentator wrote that, "[i]t would be both an over-simplification and an over-statement to dismiss American anti-bribery and anti-boycott legislation as pious and ineffectual attempts to legislate morality." 10 This comment applies equally today, twenty years after the FCPA's enactment.

Understanding the FCPA is crucial to Canadian companies. Any Canadian company which has a U.S. subsidiary or joint venture will need to have that subsidiary comply with the FCPA to the same extent that all other U.S. companies must comply. Any Canadian company which uses the U.S. capital markets will become subject to FCPA accounting requirements. Finally, any Canadian company which is a subsidiary of a U.S. company, in whole or in part, may have certain obligations under the FCPA.

The various types of releases are collected in the three-volume FCPA Rep., supra note 3. For additional information on a particular case, pleadings and other articles available are from the SEC administrative proceedings or from federal court records.

" M. Weinstein \& A.G. Newbold, "The Foreign Corrupt Practices Act and International Bribery and Corruption: Recent Developments" International Resources Law, Paper No. 7B (Denver: Rocky Mtn. Min. L. Fdn., 1997) at 7B-8.

I" E.E. Goldstein, "European Views of U.S. Anti-Bribery and Anti-Boycott Legislation" (1979) I Nw. J. Int'l L. \& Bus. 363. 


\section{Application of the FCPa to Non-U.S. Companies}

There are two main ways in which the FCPA applies to non-U.S. companies. First, the FCPA applies whenever a non-U.S. company avails itself of U.S. capital markets by issuing securities in the U.S. The FCPA applies to the same extent to all issuers of securities in the U.S. whether the company is domestic or foreign. Second, the FCPA applies to non-U.S. companies that are subsidiaries of U.S. companies.

\section{A. Direct Applicability: Issuers of Securities}

The FCPA applies to all issuers of securities in the United States. The books and records section of the $F C P A$ requires that a system of internal accounting controls be established by every issuer which either: (1) has a class of securities registered with the SEC, or (2) is required to file reports with the SEC." The anti-bribery section of the FCPA prohibits the paying of bribes by the same two categories of issuers. ${ }^{12}$ Application of these accounting and anti-bribery rules to non-U.S. companies depends upon the definitions of "issuer" and "security," and upon the requirements for registering such securities.

\section{WHAT IS AN ISSUER?}

The FCPA's definition of "issuer" is simple. An issuer is "any person who issues or proposes to issue any security" and certain persons managing trusts or using equipment under equipment-trust certificates. ${ }^{13}$ One important aspect of this definition is that it applies equally to persons who only "propose" to issue securities. Thus, a company which is merely seeking future registration of its securities with the SEC is subject to the requirements of the $F C P A$.

\section{WHAT IS A SECURITY?}

The FCPA's definition of "security" is quite broad. In general, the FCPA defines "security" as "any instrument commonly known as a 'security."'14 The FCPA's definition also lists several types of specific instruments including any "note, stock, treasury stock, bond, [or] debenture," almost any derivative based thereon, ${ }^{15}$ certificates of deposit, any group or index of securities, any instrument on a securities exchange relating to foreign currency, ${ }^{16}$ or any certificate for an interest in such an instrument. ${ }^{17}$ The definition also encompasses American depositary receipts (ADRs):

Supra note $1, \S 78 \mathrm{~m}(\mathrm{~b})(2)$.

Ibid., \$78dd-1(a).

Ibid., $\$ 78 \mathrm{c}(\mathrm{a})(8)$.

Ibid., $\$ 78 \mathrm{c}(\mathrm{a})(10)$.

In the Matter of Mitchell A. Vazquez, Exchange Act Rel. No. 36906 (29 February 1996), 3 FCPA

Rep. 699.303, 1996 SEC LEXIS 553.

SEC v. Gomez, Civ. No. 96-2056 (S.D.N.Y. 21 March 1996), SEC Litg. Rel. No. 14851, 3 FCPA

Rep. 699.306, 1996 SEC LEXIS 805.

17 Supra note $1, \$ 78 \mathrm{c}(\mathrm{a})(10)$. 
negotiable receipts issued by a U.S. bank certifying that stated numbers of shares of a foreign private issuer are on deposit with the bank. ${ }^{18}$

The FCPA's definition of "security" also includes any "certificate of interest or participation in ... any oil, gas or other mineral royalty or lease." 19 This provision covers any fractional undivided interest in oil, gas or other mineral rights, and is applied to the owner of any such right who creates fractional interests for the purpose of offering them for sale to the investing public. ${ }^{20}$ This definition applies to all undivided interests in mineral rights (such as coal leases) or other forms of ownership interests, ${ }^{21}$ although other types of non-property interests are analyzed under the rubric of investment contracts. ${ }^{22}$

\section{WHEN IS AN ISSUER REQUIRED TO REGISTER A SECURITY?}

In general, U.S. securities laws require registration of any security with the SEC at the time the security is offered for sale. ${ }^{23}$ This process involves the preparation of detailed registration documents and their approval by the SEC. There are limited exceptions to this requirement depending upon the size of the offering, the size of the issuer, the nature of the investors and the limitations to be placed upon secondary sales of the security. ${ }^{24}$

The registration requirement also applies to all securities offered for sale in the U.S. from points outside the U.S. ${ }^{25}$ The Foreign Integrated Disclosure System requires foreign private (non-governmental) issuers to furnish certain financial statements. It dictates the content of those statements and mandates that the statements be prepared according to generally accepted accounting principles in the U.S. ${ }^{26}$ The registration requirement extends as well to ADRs. ${ }^{27}$

Canadian securities issuers may fall into one of two categories under the U.S. securities laws. A Canadian company may list its securities directly for sale on a U.S. securities exchange and will be treated the same as a domestic U.S. issuer. ${ }^{28}$ Alternatively, a Canadian company may make a simultaneous offering in Canada and the U.S. under the multi-jurisdictional disclosure system (MJDS). Under the MJDS, the

SEC v. Montedison, S.p.A., Civ. No. 1:96CV02631 (D.D.C. filed 21 November 1996), SEC Litig. Rel. No. 15164, 3 FCPA Rep. 699.450, 1996 SEC LEXIS 3202.

Supra note 1, \$\$78c(10).

L. Loss \& J. Seligman, Fundamentals of Securities Regulation (Toronto: Little, Brown \& Co., 1995) at 178.

SEC v. Goldfield Deep Mines Company of Nevada, No. 83-2013 (U.S.D.C., Calif. 20 April 1983), SEC Litig. Rel. No. 9969, I FCPA Rep. 273.06, 1983 SEC LEXIS 1949 [hereinafter Nevada Goldfields].

Loss \& Seligman, supra note 20 at 183.

A.A. Sommer, ed., Securities Law Techniques (New York: Matthew Bender \& Co., 1997).

Ibid. at 1-1, 2-1ff.

Loss \& Seligman, supra note 20 at 154.

Ibid. at 155.

Ibid. at 157.

Ibid. at 154. 
Canadian company will basically use the offering documents prepared under Canadian securities laws for its registration statement in the U.S. ${ }^{29}$ Under either category, the Canadian issuer would be subject to all of the U.S. civil and criminal laws concerning fraud and corruption. ${ }^{30}$

\section{B. INDIRECT APPLICABILITY: SUBSIDIARIES OF U.S. COMPANIES}

An issuer has duties under the $F C P A$ 's books and records provisions not only with respect to itself, but with respect to its subsidiaries, whether domestic or foreign. The extent of these duties depends upon the extent of ownership by the issuer. Where a subsidiary is majority-owned by the issuer, the issuer is required to take steps to ensure that the subsidiary comply with the $F C P A$ 's requirements. "If a U.S. firm owns 50 percent or less of a foreign firm, and the U.S. firm, reasonably and in good faith, uses its influence to cause the foreign firm to make and keep accurate books and records and a system of internal accounting controls, the U.S. firm has no responsibility for the foreign firm's accounting practices." ${ }^{132}$ Thus, a conservative approach by the parent in ensuring there is no falsification of its subsidiaries' records is prudent, even though the jurisdiction of the SEC over a non-U.S. subsidiary would be questionable. ${ }^{33}$

The anti-bribery provisions of the $F C P A$ are not made expressly applicable to issuers' subsidiaries. In fact, one court has found that Congress did not intend for the anti-bribery provision to extend to foreign subsidiaries, but only to their American parent corporation. ${ }^{34}$ However, an issuer would be held liable if it corruptly takes any actions in furtherance of the proscribed payments of its offshore affiliates. A payment made by the foreign subsidiary of an issuer would violate the FCPA if the issuer knew that some or all of the payment would be given to a foreign official, whether directly by the subsidiary or indirectly, with the subsidiary giving the payment to an intermediary knowing it would eventually go to a foreign official. This "knowledge" requirement need not be actual knowledge but may be met by "conscious disregard" or "willful ignorance" of the facts. ${ }^{35}$

An issuer, a foreign subsidiary, or a foreign corporation could also be charged as an aider or abettor to a principal violator of the FCPA under Title $18, \S 2$ of the United States Code, or as a co-conspirator under Title 18, United States Code. ${ }^{36}$

29 Ibid. at 166-67.

$30 \quad$ Ibid. at 168.

3 Supra note $1, \$ 78 \mathrm{~m}(\mathrm{~b})(5)$; L. Low, "The Extraterritorial Reach of U.S. Laws to the Interests in Natural Resource Projects in Latin America" International Oil, Gas \& Mining Development in Latin America, Paper No. 3 (Denver: Rocky Mtn. Min. L. Fdn., 1994) at 3-7.

Chen, supra note 4 at 101.025 .

Ibid. at 101.128.

Dooley v. United Technologies Corp., 803 F.Supp. 428 (D.D.C. 1992) [hereinafter Dooley].

Bialos \& Husisian, supra note 3 at 103.027.

R. Shine, "Enforcement of the Foreign Corrupt Practices Act by Department of Justice" (1982) 9 Syracuse J. Int'l L. \& C. 283 at 285. 


\section{REQUIREMENTS OF THE FCPA}

\section{A. BOOKS AND RECORDS}

As previously noted, the word "Foreign" in the title of the FCPA gives an incorrect impression of the Act. The accounting requirements of the FCPA apply to all companies issuing securities in the U.S., and most of the enforcement actions under the FCPA have involved accounting questions within the U.S. rather than allegations of foreign bribery. In fact, the $F C P A$ has been called "the most important act affecting accounting since the Securities Acts of 1933 and 1934."37

It is therefore necessary to review briefly the accounting standards required by the $F C P A$, and to then survey the enforcement actions against non-U.S. companies, and companies in the resources industries, which applied these accounting standards.

\section{STANDARDS}

The basic FCPA requirement is that all issuers "make and keep books, records and accounts which, in reasonable detail accurately and fairly reflect the transactions and dispositions of the assets of the issuer." 38 To this is added the requirement that all issuers "devise and maintain a system of internal accounting controls sufficient to provide reasonable assurances" that certain levels of detail are met. ${ }^{39}$ While simple in definition, the details of these accounting requirements can be very complex. ${ }^{40}$

The SEC has enforcement authority over the accounting provisions and the anti-bribery provisions as they apply to issuers. When the SEC encounters accounting problems that do not involve improper payments, it typically seeks a civil injunction to get a company to change its bookkeeping methods. Generally, a company that has not proffered corrupt payments is not likely to be criminally prosecuted under the accounting provisions alone. ${ }^{41}$

Most criminal enforcement actions for FCPA record keeping violations also appear to involve corrupt payments to foreign officials as well. However, criminal penalties cannot be imposed merely for technical infractions of the FCPA's books and records or accounting control provisions. ${ }^{42}$

37 (1979) 12 Vand. J. Transnat'I L. 689 at 692n.18.

38 Supra note $1, \$ 78 \mathrm{~m}(\mathrm{~b})(2)(\mathrm{A})$ [emphasis added].

3) Ibid., $\$ 78 \mathrm{~m}(\mathrm{~b})(2)(\mathrm{B})$.

4. M.S. Spindler, "What You Always Wanted to Know About the Accounting Provisions of the Foreign Corrupt Practices Act (But Were Afraid to Ask)" (1998) 36 Alta. L. Rev. 473.

$4 \quad$ Hancock, supra note 5 at 100.012; Bialos \& Husisian, supra note 3 at 103.010 .

42 Bialos \& Husisian, ibid. at 103.027n.38 citing H.R. Con. Res. 576, 100th Cong., 2d Sess. at 918 (1988) (reprinted in 2 FCPA Rep. 373). 


\section{ENFORCEMENT ACTIONS}

The very first $F C P A$ case involved a U.S. coal company, Aminex Resources (Aminex). No foreign companies or transactions were involved. This was an alleged fraud case involving misappropriation of corporate funds, kickbacks, and personal use of corporate proceeds, none of which (of course) was accurately or fairly reflected in the company's accounting records as required by the $F C P A$. The case illustrated that violations of the FCPA's record keeping provisions would become standard in SEC enforcement actions. The court enjoined Aminex and its officers from further violations, and appointed a receiver for the company. ${ }^{43}$

A 1986 case best illustrates how the $F C P A$ accounting provisions can apply to Canadian companies. ${ }^{44}$ In 1986, the SEC filed a complaint against Golden Bear Resources Ltd. (Golden Bear), a Canadian corporation trading on the Vancouver Stock Exchange. Also named were Canadian promoters of the stock, and a State of Washington stock brokerage company and several of its officers. The complaint charged that 500,000 shares of stock were sold in the U.S. without being registered with the SEC, that the market price was manipulated by issuing false press releases, and that FCPA records and reporting violations had occurred.

In 1987 and 1988, the court found ten defendants guilty of manipulating the stock by placing false orders with the Spokane brokerage, by making false statements about acquiring oil producing property in Alaska, and other FCPA reporting violations. The court noted that the fraud had been "brought to a halt [by] the prompt actions of the SEC. ${ }^{, 45}$

In 1989, the judgment was amended against one of the defendants, Kazimit Golac, a resident of Vancouver. The amended judgment ordered Golac to pay (Cdn.) $\$ 1,107,097$, the amount of fraudulently obtained profits he received from the sale of Golden Bear stock. The amended judgment also found that the value of the stock sold by Golac was created entirely by Golac's fraudulent promotion of the stock in the U.S., involving false statements, omissions and market manipulation - all violations of U.S. securities laws including the $F C P A{ }^{46}$

Perhaps the best way to understand the nature of $F C P A$ enforcement actions is to briefly review the cases involving non-U.S. companies or natural resources companies. These cases are summarized as follows:

- Officers of Enron Oil, a subsidiary of Enron Corporation, allegedly exceeded internal trading limits, established offshore corporations, engaged

44 SEC v. Golden Bear Resources Ltd., No. C-86-736-JLQ (U.S.D.C. 26 September 1986), SEC Litig. Rel. No. 11228, 1986 SEC LEXIS 704 [hereinafter SEC v. Golden Bear].

4s $\quad$ SEC v. Golden Bear, ibid., SEC Litig. Rel. No. 11861, 1988 WL 1054, 1988 SEC LEXIS 1867.

\$6 Ibid., Litig. Rel. No. 12088, 1989 WL 257132, 1989 SEC LEXIS 873. 
in sham transactions to conceal unauthorized trading and used a single brokerage company which kicked back brokerage fees. A permanent injunction was entered without admission or denial of charges. ${ }^{47}$

- An officer of a Canadian subsidiary of a U.S. issuer falsely reported debt of the subsidiary to the parent, knowing a U.S. auditor would rely on the statement. The officer was ordered to cease and desist from aiding and abetting violations of securities laws. ${ }^{48}$

- An offer and sale of ore interests involving misstatements of material facts regarding the amount of assets, the risk in purchasing ore interests, and the existence of offshore financial institutions, violates the $F C P A$. A preliminary injunction was issued, assets frozen, and a receiver appointed. ${ }^{49}$

- Several officers of a company listed on the New York Stock Exchange, one Swiss and two Italians, were ordered to cease and desist from further securities violations in a sham sale and leaseback of European properties involving several European banks including Credit Lyonnais, S.A. ${ }^{\mathbf{s 0}}$

- A U.S. corporation and its Cayman Islands subsidiary which falsely reported (U.S.) $\$ 20$ million in revenues violated the $F C P A$. An injunction was issued and bankruptcy filed. ${ }^{51}$

- A U.S. corporation, its officer and a British West Indies corporation controlled by that officer violated the $F C P A$ by knowingly overstating net worth by 1,000 percent, failing to file reports and failing to keep reasonably detailed or accurate books, and failing to devise and maintain internal controls. An injunction was issued with other relief. ${ }^{52}$

- A U.S. corporation failed to report difficulties in refinancing loans, loss of trade credit and write-down of its Bahamas-based refinery. A settlement was reached with the CEO and CFO; an injunction was issued. ${ }^{53}$

SEC v. Borget, Civ. No. $91-1682$ (D.D.C. 11 July 1991), SEC Litig. Rel. No. 12900, 1 FCPA Rep. 273.62, 199I SEC LEXIS 1322.

In the Matter of Fred Engelbrechten, Exchange Act Rel. No. 30173 (9 January 1992), 3 FCPA Rep. 699.029, 1992 SEC LEXIS 76.

See Nevada Goldfields, supra note 21.

In the Matter of Fernando Cappuccio, Exchange Act Rel. No. 36670 (3 January 1996), 3 FCPA Rep. 699.271, 1996 SEC LEXIS 7; In the Matter of Florio Fiorini, Exchange Act Rel. No. 36669 (3 January 1996), 3 FCPA Rep. 699.274, 1996 SEC LEXIS 6; Parretti, infra note 74.

SEC v. Flight Transportation Corp., 669 F.2d 943 (D. Minn. 2 February 1983).

$S E C$ v. William Bundy, No. IP 81-1350C (S.D. Ind., 18 December 1981), SEC Litig. Rel. No. 9532, 1 FCPA Rep. 273.15, 1981 SEC LEXIS 84.

In the Matter of Ray M. Vanlandingham and Wallace A. Patzke Jr., Exchange Act Rel. No. 23349 (20 June 1986), 1986 SEC LEXIS 1320. 
- An oil and gas company, Cayman Resources Corp., was enjoined from continuing to fail to file reports. ${ }^{54}$

- Officers of a U.S. company, including its general counsel, who failed to disclose the purchase of a controlling interest in the company by families from Dubai and the United Arab Emirates, were enjoined from further violations of the $F C P A .^{55}$

- A U.S. citizen was twice convicted for failing to disclose material facts concerning various U.S. and non-U.S. corporations, and two of his attorneys were barred from practicing before the SEC. ${ }^{56}$

- Reporting forged bank notes as assets resulted in the conviction of three individuals, including a British national. ${ }^{57}$

- Three individuals were enjoined from further violations after fraudulently inflating the assets of Standard Oil and Exploration of Delaware, Inc. ${ }^{58}$

\section{B. ANTI-BRIBERY}

\section{DEFINITION OF BRIBERY}

The U.S. Department of Justice has primary authority to bring actions for enforcing the anti-bribery provisions of the FCPA. This includes actions against domestic concerns and "issuers" for injunctive relief. ${ }^{59}$ As such, the DOJ is authorized to bring actions against non-U.S. companies, including Canadian companies, which are issuers of securities under the $F C P A$, for violations of the anti-bribery provisions. Only a small number of such cases have been brought, but the cases against U.S. companies provide insight into what will be considered proscripted conduct under the FCPA.

It must also be noted that the DOJ has a procedure for obtaining pre-action review of proposed activities. This enables companies to seek guidance before entering into transactions to which the application of FCPA strictures is unclear. However, the process is slow and highly ineffective, as shown by the fact that only some thirty-six

SEC v. Cayman Resources Corporation, Civ. No. 96-CV-00968 (D.D.C. 26 April 1996), SEC Litig. Rel. No. 14894, 1 FCPA Rep. 273.78, 1996 SEC LEXIS 1227.

ss In the Matter of Roger Rosenberg, Exchange Act Rel. No. 36317 (29 September 1995), 3 FCPA Rep. 699.241, 1995 SEC LEXIS 2574.

s6 SEC v. Sarivola, 95 Civ. 9270 (S.D.N.Y. 31 October 1995), 3 FCPA Rep. 699.263, 699.353, 1995 SEC LEXIS 3010.

s7 SEC v. Cunningham, No. CIV94-2001 (11 June 1996), SEC Litig. Rel. No. 14945, 3 FCPA Rep. 699.348, 1996 SEC LEXIS 1558.

58 SEC v. Klenovic, No. 94-909-CIV-T-23E (M.D. Fla., 6 January 1997), SEC Litig. Rel. No. 15206, 3 FCPA Rep. 699.461, 1997 SEC LEXIS 24.

s" Supra note $1, \$ 78 \mathrm{dd}-2$ (d). The FCPA does not provide a private cause of action. Lamb v. Philip Morris, Inc., 915 F.2d 1024 (6th Cir. 1990); Citicorp Int'l Trading Co. v. Western Oil \& Ref. Co., 771 F.Supp. 600 (S.D.N.Y. 1991). 
decisions have been issued under this procedure in the twenty years since the $F C P A$ was enacted.

Under the $F C P A$, there are six elements which the government must prove in order to demonstrate that bribery of a foreign official has occurred. ${ }^{60}$ These elements are:

(1) Interstate commerce used

(2) Payment or value

(3) Received by a foreign official

(4) Corrupt intent

(5) Desire for influence

(6) Business objective

Three of these elements are easily found. "Interstate commerce" can be as simple as travel on a commercial airline in the context of a transaction. "61 "Payment or value" can be monetary payments, non-cash transactions, or even a mere offer or promise to pay a government official, although one may also be charged with payments made by local agents or partners if the payment is made with knowledge of the issuer. ${ }^{62}$ "Business objective" simply requires that the payment must have been given with the objective to obtain, retain or direct business to any person. ${ }^{63}$

The three remaining elements required to prove an FCPA violation are less easily definable. The recipient of a payment must be a foreign official, an official of a foreign political party, or a candidate for foreign political office. This definition can cast a wide net, catching a person appointed for a special task, ${ }^{64}$ or a special advisor, ${ }^{65}$ but simply being related to a government official is not enough to make the relative a foreign official for FCPA purposes. ${ }^{66}$ The FCPA does not restrict payments that might appear as "corrupt," such as payments made to private persons to obtain business from private foreign companies. ${ }^{67}$ Note, in addition, that the foreign official may not be prosecuted for conspiracy to violate the FCPA; the FCPA only applies to issuers, subsidiaries and domestic concerns. ${ }^{68}$

Perhaps the most telling element of an FCPA violation is "corrupt intent." The government must prove that the required mental state, corrupt intent, coexisted with the

See Appendix A for a list of the "red flags" which are likely to lead to a criminal investigation by the DOJ.

Low, supra note 31 at 3-12.

Low, ibid. at 3-13. For an excellent discussion on the use of foreign agents, see Department of Justice Release 81.01 (25 November 1981), I FCPA Rep. 101.036.

Supra note $1, \$ 78 \mathrm{dd}-1$ (a).

Low, supra note 31 at 3-13, citing U.S. v. Young \& Rubicam Inc., 741 F.Supp. 334 (D. Conn. 1990).

Ibid. at 3-14, citing Ashland, infra note 78.

Ibid. at 3-14, citing Department of Justice Review Release No. 84-1 (16 August 1984).

Schuchat, supra note 2 at $7 \mathrm{~A}-5$.

U.S. v. George Morton, Cr. No. 3-90-061 (N.D. Tex. 15 Mar. 1990) [hereinafter Morton]. The FCPA does not create an exception to the "act of state" doctrine; see 1 FCPA Rep. at 101.071 and cases cited therein. 
act. This is never an easy task, and must usually be shown through circumstantial evidence. However, the type of payment involved has been used to show the requisite intent. The legislative history of the FCPA shows that the types of payments that gave rise to enactment of the $F C P A$ were payments by government contractors to secure government military contracts in competitive bidding situations. Most of the prosecutions under the $F C P A$ also involve this precise type of payment (for government contracts in one form or another), and, hence, anything given to secure a government contract gives particular cause for concern. ${ }^{69}$

The final element of an FCPA violation, "desire for influence," may be the key to determining if actionable conduct has occurred. The determining factor appears to be an attempt to get a foreign official to exercise his or her discretion in a way that would benefit the offeror. ${ }^{70}$ This can be contrasted with "facilitation" payments, ${ }^{71}$ which are not "bribery," and which concern ministerial acts not involving the application of an official's discretionary powers. Facilitation payments are made to ensure or speed up the performance of repetitive tasks, and a list of such tasks is provided in the FCPA itself. $^{72}$

Proving the elements of bribery may become easier in the future. It has been noted that, due to expanding anti-bribery laws and treaties, and due to such "world-shrinking" factors as ease of travel and the Internet, the ability to gather evidence in foreign countries has increased. The result is an increasing availability to U.S. prosecutors of records of middlemen, bank accounts and witnesses attendant to foreign transactions which provide the most compelling evidence in FCPA cases. ${ }^{73}$ In at least one case, the SEC has acknowledged the contributions made by several foreign securities regulators and governmental authorities in the Netherlands, France, Switzerland and Italy. ${ }^{74}$

\section{APPLICATION TO NON-U.S. COMPANIES}

The most glaring example of application of the $F C P A$ anti-bribery provisions to a non-U.S. company is the case of SEC v. Montedison, S.p.A. ${ }^{75}$ This case, filed in 1996, is the first in which the issuer is a foreign company and all the allegedly illegal conduct took place outside the U.S. Montedison is an Italian company which trades in ADRs on the New York Stock Exchange and is therefore registered with the SEC.

U.S. v. Richard Liebo, 923 F.2d 1308 (Minn. 8th Cir. 15 January 1991) [hereinafter Liebo]. Low, supra note 31 at 3-16; see also U.S. v. Rodriquez, 2 FCPA Rep. 690.7 (agreement to pay a bribe to induce the chairman of a racing commission to "use his influence"); U.S. v. F.G. Mason Engineering Co., No. B-90-29 (D. Conn. 25 June 1990), 2 FCPA Rep. 698.70.

Originally called "grease" payments in the FCPA.

See Appendix B for examples of "facilitation" payments.

W. Pendergast, "Foreign Corrupt Practices Act: An Overview of Almost Twenty Years of Foreign Bribery Prosecutions" (1995) 7 Int'। Q. 187, I FCPA Rep. 102.014 [hereinafter Pendergast, cited to FCPA Rep.].

SEC v. Giancarlo Parretti, Civ. No. 1:96CV00013 (D.D.C. 3 January 1996), SEC Litig. Rel. No. 14770, 3 FCPA Rep. 699.279, 1996 SEC LEXIS 5 [hereinafter Parretti].

Supra note 18. 
The case alleges two schemes: first, that Montedison disguised numerous bribes as fictitious loans and then entered the loans as uncollectible on its 1992 balance sheet, and, second, that the company overstated the value of real estate and reported a separate write-down of (U.S.) $\$ 120$ million. In essence, the SEC is alleging that Montedison's schemes enabled it to conceal hundreds of million of dollars in payments that, among other things, were used to bribe Italian politicians. As of this writing, no further action in the case has been reported.

\section{EXAMPLES OF BRIBERY BY NON-U.S. COMPANIES}

Once again, the best way to understand the nature of FCPA anti-bribery enforcement actions appears to be to review briefly the anti-bribery cases involving non-U.S. companies or natural resources companies. These cases are summarized as follows:

- In the Pemex cases, several U.S. corporations, including International Harvester and Ruston Gas Turbines, and several U.S. individuals, were convicted and fined for bribing Mexican officials through a scheme involving payment of a 5 percent "commission" by the companies' local agents to the government officials to ensure that compression equipment contracts would be obtained. ${ }^{76}$

- Tesoro Petroleum Co. was charged with paying "consultants" and "finders" disproportionate sums, knowing that the funds would eventually go to foreign officials to secure oil and gas concessions, and the company consented to an injunction as well as to the appointment of a new director satisfactory to the SEC. ${ }^{77}$

- A subsidiary of Ashland Oil Co. was charged with purchasing a worthless Rhodesian chromite mine from an Omani official (a British national given a government position in Oman) in order to persuade him to use his influence to enable Ashland to obtain crude oil contracts from the government. A permanent injunction was agreed to. ${ }^{78}$

- The U.S. president and vice-president of a Cayman Islands oil company were charged with bribing an official of Qatar to obtain an oil concession. $^{79}$ A permanent injunction was entered against them, and one of the prosecutors noted, "[w]e reached [them] ... because they were United States citizens, ... even though they were theoretically operating through a foreign corporation."

The Pemex cases are collected in I FCPA Rep. 696.33ff.

SEC v. Tesoro Petroleum Corp., No. 80-2961 (D.D.C. 20 November 1980), SEC Litig. Rel. No. 9236, 2 FCPA Rep. 637, 1980 SEC LEXIS 294.

SEC v. Ashland Oil Inc., Civ. No. 86-1904 (D.D.C. 8 July 1986), Sec. Litig. Rel. No. 11150, 2 FCPA Rep. 696.95, 1986 SEC LEXIS 2332 [hereinafter Ashland].

U.S. v. Roy Carver and Eugene Holley, (S.D. Fla. 1979), 2 FCPA Rep. 645. For further details see Sedco International, S.A. v. Cory, 522 F. Supp. 254 (S.D. Iowa, 1981).

Shine, supra note 36 at 285. 
- Other examples of bribery include: flying voters from New Zealand to the Cook Islands to ensure re-election of the Premier, in order to guarantee renewal of government stamp concession; ${ }^{81}$ hiring an agent to bribe political and military figures to win an equipment contract in Nigeria; ${ }^{82}$ paying 10 percent of net revenues on certain contracts to officials of the government of Niger for aircraft parts and maintenance, ${ }^{83}$ and paying $\$ 50,000(\mathrm{Cdn}$.) to the president of a Canadian Crown corporation to ensure the award of a bus purchase contract. ${ }^{84}$

\section{APPLICATION TO NON-U.S. INDIVIDUALS}

The civil and criminal enforcement provisions of the FCPA apply not only to issuers and U.S. companies, but to individuals as well. ${ }^{85}$ Many U.S. citizens have been caught in the net of $F C P A$ violations. ${ }^{86}$ In some circumstances, the $F C P A$ can be applied to foreign individuals who are directors, employees or agents of issuers. If a foreign person has purposefully established "minimum contacts" in the U.S., the American courts can have jurisdiction and the $F C P A$ can be applied. ${ }^{87}$

The most publicized example of an individual being prosecuted for FCPA violations occurred in the Lockheed Corporation (Lockheed) case. Ironically, Lockheed's guilty plea in the 1994 case brought FCPA enforcement "full circle" because of Lockheed's guilty plea in 1979 to payoffs to Prime Minister Tanaka of Japan in another case. ${ }^{88}$

Lockheed was charged in 1995 with paying a (U.S.) \$1 million bribe to a member of the Egyptian parliament, Dr. Leila Takla, in order to secure the sale of three C-130 airplanes to the Egyptian military. Lockheed's payment of the bribes came to light via an employee who later claimed he was fired in retaliation for his disclosure of the information. ${ }^{89}$ Lockheed pled guilty to FCPA violations and paid (U.S.) $\$ 24.8$ million in fines and civil penalties.

Two individuals were implicated. Most significantly, a Lockheed vice-president in charge of Africa who was not a U.S. citizen, Suleiman Nassar, fled to Syria after being indicted. He was extradited and returned to the U.S. and became the first individual jailed for an FCPA violation, as well as being fined (U.S.) $\$ 125,000$. Also, a retired manager and U.S. citizen pled guilty to conspiracy charges and was fined (U.S.) $\$ 20,000 .^{90}$

U.S. v. Kinney Int'l Corp., 2 FCPA Rep. 649 (D.D.C. 1979).

Environmental Techtonics v. W.S. Kirkpatrick Inc., 847 F.2d 1052 (U.S.C.A. 3d Cir. 2 May 1988).

Liebo, supra note 69.

Morton, supra note 68.

Supra note $1, \$ 78 \mathrm{dd}-1$ (a); $\$ 78 \mathrm{dd}-2$ (a).

See e.g. the Pemex cases, supra note 76.

Dooley, supra note 34 at 440.

Pendergast, supra note 73 at 102.001 .

Weinstein \& Newbold, supra note 9 at 7B-17n.38. U.S. v. Lockheed Corp., No. 1:94-CR226 (N.D. Ga. Atlanta Div. June 1994) [hereinafter Lockheed].

Weinstein \& Newbold, ibid. at 7B-8. 
While Lockheed represents the clearest example of a non-U.S. citizen being affected by the $F C P A$, and the only example of an individual serving jail time, other examples illustrate that $F C P A$ liability goes beyond the companies themselves. Examples include:

- A U.S. company which paid (Cdn.) $\$ 50,000$ to the president of a Canadian Crown corporation to ensure the award of a bus purchase contract was permanently enjoined from further FCPA violations, and its agent, a Canadian citizen, pled guilty to conspiracy to violate the $F C P A$ and received three years' probation. ${ }^{91}$

- A U.S. company which paid 10 percent of net revenues on certain government contracts to officials of the government of Niger for aircraft parts and maintenance was enjoined from further violations, and its U.S. president was sentenced to three years' probation. ${ }^{92}$

- A U.S. company and one of its employees were charged with paying an Israeli agent some (U.S.) $\$ 10$ million to obtain inside information and arrange meetings with government officials relating to a lucrative helicopter contract with the Israeli government. The company was permanently enjoined from charging a commission in the contract, and the employee pled guilty to defrauding the U.S. government. ${ }^{93}$

- It has been reported that the DOJ is investigating whether De Havilland Aircraft, which is owned by Bombardier of Montreal and the government of Ontario, has paid bribes to officials of the Bahamian government in order to win a $\$ 64$ million aircraft contract. Officers of the company, consultants and government officials are reportedly under investigation as well. The probe follows a similar investigation by the RCMP and the 1995 issuance of a Bahamas government commission report concluding that De Havilland and Boeing of Canada Ltd. hired consultants for the corrupt purpose of bribing two ministers. ${ }^{94}$

- In February 1997, the SEC filed a complaint against Triton Energy Corporation (Triton Energy), a U.S. corporation, and two officers of its Indonesian subsidiary, Triton Indonesia, alleging payments to an agent with knowledge that the payments would be passed along to government employees to gain certain oil- and gas-related contracts. The complaint also alleges that the payments were falsely documented and reported, and that Triton Energy failed to keep proper books and records or an adequate system of internal accounting controls. However, the complaint also notes

Morton, supra note 68.

Pendergast, supra note 73 at 102.007.

Weinstein \& Newbold, supra note 9 at 7B-9-10.

Ibid. at 7B-11-12. 
that Triton Energy did not expressly authorize or direct these improper payments or the misbooking of Triton Indonesia. ${ }^{95}$

\section{CONCLuSION}

FCPA convictions of non-U.S. companies may be relatively rare. However, "for business people, the fear of conviction is not always the controlling deterrent; more often, the fear of publicity, investigation and prosecution are." ${ }^{96}$ Thus, the mere threat of an FCPA enforcement action is reason to understand the requirements of the Act.

The FCPA is largely an accounting law which has application to any non-U.S. company with U.S. subsidiaries, which issues securities in the U.S. to raise money, or which is in whole or in part a subsidiary of a U.S. company. The anti-bribery provisions of the FCPA apply to these companies as well, and the vigour of the enforcers of the law appears to be increasing.

The FCPA has relevance to many Canadian resources companies, and should not be disregarded merely as another attempt by the U.S. at extraterritorial application of its laws. The numerous forms of contact between U.S. and Canadian resource companies present fertile ground for inadvertent, and costly, violations of this wide-reaching law. 


\section{APPENDIX A}

\section{"Red flags" for existence of bribery:}

- Off-book accounts

- Shell or sham corporations

- Sham transactions

- No knowledge of the Board of Directors

- No outside audit committee responsibilities

- Information not disclosed to outside auditors

- Less than full disclosure to the SEC

- Shady reputation of the foreign agent

- Excessive commission given for the transaction

- Refusal by the foreign agent to give $F C P A$ representations

- Connection of the foreign agent to the government

- Payments of cash

- Payments to third parties or third country accounts

- Unusual bonuses paid to foreign operational managers which lack adequate support 


\section{APPENDIX B}

"Facilitation" payments include payments for:

- Actions ordinarily and commonly performed by foreign officials in obtaining permits, licenses or other documents to qualify persons to do business in the foreign country

- $\quad$ Processing visas

- Providing police protection

- Mail pick-up and delivery

- Scheduling inspections required for performance of contracts or for cross-country transit of goods

- Providing phone, power and water supply

- Loading or unloading of cargo

- Other similar actions 